УДК 546.05+539:232+546.492:546.22

\title{
OPTIMIZATION OF SYNTHESIS CONDITIONS OF HgS THIN FILMS
}

\author{
M. Sozanskyi*, V. Stadnik, R. Guminilovych, \\ P. Shapoval, M. Laruk, Yo. Yatchyshyn \\ Lviv Polytechnic National University, \\ S. Bandera Str., 12, 79013 Lviv, Ukraine \\ e-mail: martyn.a.sozanskyi@lpnu.ua
}

\begin{abstract}
The mercury sulfide $(\mathrm{HgS})$ films were obtained on glass substrates via the chemical deposition method. The aqueous solutions of mercury(II) nitrate, thiourea and trisodium citrate were used. X-ray and elemental analysis of the film sample were made. The effect of concentrations of initial reagents, deposition duration and temperature on the mass of $\mathrm{HgS}$ coatings was investigated and their thickness were calculated. The optical and morphological properties of $\mathrm{HgS}$ coating were examined.
\end{abstract}

Keywords: mercury sulfide, thin films, chemical deposition, optical properties.

DOI: https://doi.org/10.30970/vch.6001.146

The mercury sulfide $(\mathrm{HgS})$ film is one of the least investigated material of zinc subgroup metal chalcogenides [1]. The $\mathrm{HgS}$ coatings have potential use in solid state solar cells, photoelectrochemical cells etc. The one of the simplest methods for semiconductor films obtaining is chemical deposition [2]. This method based on synthesis at low temperature $(<373 \mathrm{~K})$ and duration from aqueous solutions, which consist of the metal salt, complexing agent, chalcogenizer and, if it's necessary, the pH-regulator. Previously, the anodic stripping voltammetry method was used for the optimization of these parameters for synthesis of zinc and cadmium chalcogenides semiconductor films [3-5]. The series of films samples had dissolved in hydrochloric acid, then the measurements of metal content were made. In the case of mercury, this is difficult to apply, so the optimization of chemical deposition of $\mathrm{HgS}$ films could be done by gravimetric measurements.

Chemical deposition of $\mathrm{HgS}$ films was carried out on preliminarily cleaned square shape glass substrates with the total area of $64.8 \mathrm{~cm}^{2}$. The composition of the working solutions were follows: $0.0025-0.015 \mathrm{M}$ of mercury(II) nitrate $\left(\mathrm{Hg}\left(\mathrm{NO}_{3}\right)_{2}\right), 0.01-0.05 \mathrm{M}$ of thiourea $\left(\mathrm{NH}_{2}\right)_{2} \mathrm{CS}$, as a complexing and chalcogenizing agent for $\mathrm{Hg}^{2+}$ at the same time; and $0.015-0.021 \mathrm{M}$ of trisodium citrate $\left(\mathrm{Na}_{3} \mathrm{C}_{6} \mathrm{H}_{5} \mathrm{O}_{7}\right)$, as a $\mathrm{pH}$ regulator. The deposition was made in a glass bath during 0.5-7 minutes at a temperature of 323-363 K. After this, the substrates were removed, washed with distilled water and dried in the air. The films samples were dark-brown in color. Their adhesion to the glass substrate was weak. The films were easily removed at applying of small mechanical efforts.

Experimental arrays of intensities and angles of reflection of the test samples were obtained on a DRON-3.0 X-ray diffractometer ( $\mathrm{Cu} K_{\alpha}$-radiation). Preliminary processing of the experimental diffraction arrays in order to identify the phases were carried out using PowderCell program [6].

(C) Sozanskyi M., Stadnik V., Guminilovych R. et al., 2019 
M. Sozanskyi, V. Stadnik, R. Guminilovych et al.

The optical absorption spectra of the films were measured with Xion 500 "Dr. Lange" spectrophotometer in the wavelength range of 340-900 nm. The accuracy of the optical transmission detection was $\pm 0.5 \%$.

Investigation of the films surface morphology were performed on Atomic Force Microscope (AFM) MultiMode Nanoscope IIIa (Bruker) in tapping mode using Super Sharp Silicon tips SSS-NCLR (Nanosensors) with typical spring constant $\mathrm{k}=33 \mathrm{~N} / \mathrm{m}$ and resonance frequency about $180 \mathrm{kHz}$.

Elemental analysis of film was carried out on an X-ray fluorescence (XRF) spectrometer ElvaX Light SDD (Elvatech).

The $\mathrm{pH}$ of the working solutions were measured with a $\mathrm{pH}-150 \mathrm{MI} \mathrm{pH}-$ meter, using a glass combined electrode.

In order to optimize the deposition process, the gravimetric measurements were carried out. The mass of deposited $\mathrm{HgS}$ films were recalculated to the unit of the substrate square. For this purpose, the differences of substrates mass before and after deposition has been measured and the differences in mass were established. The weighing of the samples were carried out on with the use of Radwag AS 220.R2 analytical weight (accuracy $0.0002 \mathrm{~g}$ ) depending on the concentrations of initial reagents in the working solution, the duration and temperature of deposition.

To conduct the research on optimization of $\mathrm{Hg}$-containing salt initial concentration the working solutions were prepared with $0.02 \mathrm{M}$ thiourea and $0.015 \mathrm{M}$ trisodium citrate. Concentration of $\mathrm{Hg}\left(\mathrm{NO}_{3}\right)_{2}$ varied from 0.0025 to $0.015 \mathrm{M}$. The temperature of process was $363 \mathrm{~K}$. The deposition duration was 5 minutes.

To conduct the research of optimization of initial concentration of thiourea, the working solutions were prepared with $0.01 \mathrm{M}$ mercury(II) nitrate and $0.15 \mathrm{M}$ trisodium citrate. Concentration of $\left(\mathrm{NH}_{2}\right)_{2} \mathrm{CS}$ was varied from 0.01 to $0.05 \mathrm{M}$. The temperature of process was $363 \mathrm{~K}$. The deposition duration was 5 minutes.

To conduct the research of optimization of initial concentration of trisodium citrate, the working solutions were prepared with $0.01 \mathrm{M}$ mercury(II) nitrate and $0.04 \mathrm{M}$ thiourea. Concentration of $\mathrm{Na}_{3} \mathrm{C}_{6} \mathrm{H}_{5} \mathrm{O}_{7}$ was varied from 0.0015 to $0.021 \mathrm{M}$. The temperature of process was $363 \mathrm{~K}$. The deposition duration was 5 minutes.

To conduct the research on optimization of deposition time, the working solutions were prepared with $0.01 \mathrm{M}$ mercury(II) nitrate, $0.04 \mathrm{M}$ thiourea and $0.015 \mathrm{M}$ trisodium citrate. The temperature of process was $363 \mathrm{~K}$. The deposition duration varied from 0.5 to 7 minutes.

To conduct the research on optimization of deposition temperature the working solutions were prepared with $0.01 \mathrm{M}$ mercury(II) nitrate, $0.04 \mathrm{M}$ thiourea and $0.015 \mathrm{M}$ trisodium citrate. The deposition duration was 5 minutes. The temperature of process varied from $323 \mathrm{~K}$ to $363 \mathrm{~K}$.

The calculation of $\mathrm{HgS}$ films thickness according to the measured mass of coatings were carried out based on the following considerations:

1. The volume of the deposited film on the substrate equal:

$$
\mathrm{V}=\frac{\Delta \mathrm{m}}{\rho}=\frac{\mathrm{m}_{2}-\mathrm{m}_{1}}{\rho} \quad\left[\mathrm{cm}^{3}\right]
$$

where $\Delta \mathrm{m}$ is the film mass, $\mathrm{g} ; \mathrm{m}_{1}$ is the mass of substrate before synthesis, $\mathrm{g} ; \mathrm{m}_{2}$ is the mass of substrate after synthesis, $\mathrm{g}$; $\rho$ is the compound density, $\mathrm{g} / \mathrm{cm}^{3}\left(8.10 \mathrm{~g} / \mathrm{cm}^{3}\right.$ for $\left.\mathrm{HgS}\right)$. 
2. Since the synthesis were performed on substrates with the square shape, it is possible to assume that the coatings had approximately the shape of the parallelepiped and the volume of the film is:

$$
\mathrm{V}=\mathrm{S} \cdot \mathrm{d} \quad\left[\mathrm{cm}^{3}\right],
$$

where $\mathrm{S}$ is the substrate surface square, $\mathrm{cm}^{2}, \mathrm{~d}$ is the height (thickness) of the film, $\mathrm{cm}$.

3. Equating (1) and (2) we can derive a formula for calculating the average thickness of $\mathrm{HgS}$ films from the mass of coating:

$$
\mathrm{d}=\frac{\mathrm{m}_{2}-\mathrm{m}_{1}}{\mathrm{~S} \cdot \rho} \quad[\mathrm{cm}] .
$$

In nanometre size (which is more convenient for thin films) and considering that the film is deposited on both sides of the substrate it can be presented as follows:

$$
\mathrm{d}=\frac{\mathrm{m}_{2}-\mathrm{m}_{1}}{2 \mathrm{a}^{2} \cdot \rho} \cdot 10^{-7} \quad[\mathrm{~nm}],
$$

where $\mathrm{a}-$ is length of the substrate side.

By measuring of the deposited $\mathrm{HgS}$ films mass, the dependences of its changes on the synthesis conditions were constructed. According to equation (4), the films thicknesses were calculated. The research results are presented in Fig. 1 and Fig. 2.

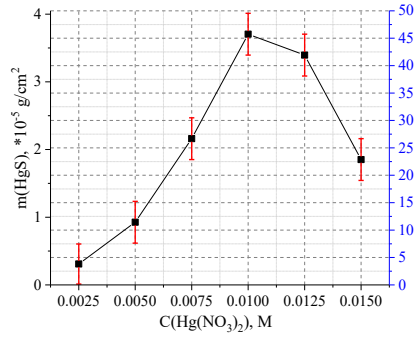

$a$

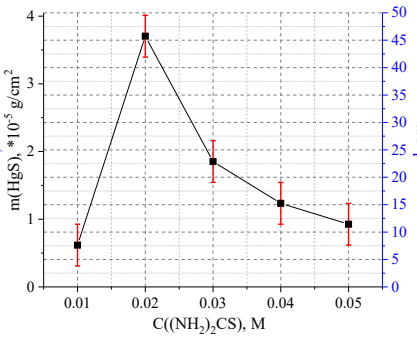

$b$

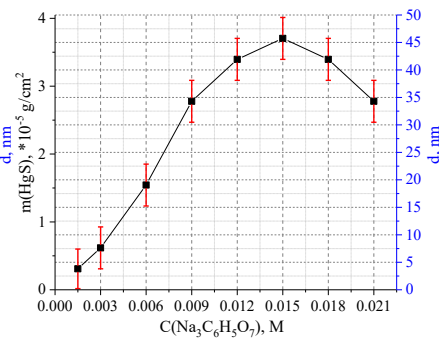

$c$

Fig. 1. Dependences of the $\mathrm{HgS}$ mass changes per unit of substrate surface area on the concentration of: $a-\mathrm{Hg}$-containing salt; $b-\left(\mathrm{NH}_{2}\right)_{2} \mathrm{CS} ; c-\mathrm{Na}_{3} \mathrm{C}_{6} \mathrm{H}_{5} \mathrm{O}_{7}$

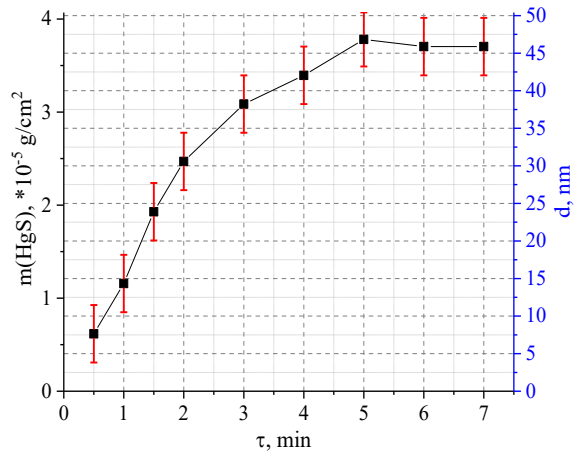

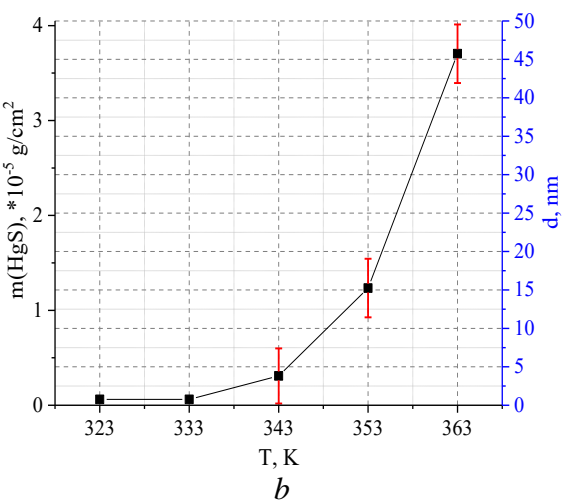

Fig. 2. Dependences of the $\mathrm{HgS}$ mass changes per unit of substrate surface area on: $a$ - deposition duration; $b$-temperature of synthesis 
M. Sozanskyi, V. Stadnik, R. Guminilovych et al.

From the obtained data (Fig. 1,a), it is seen that at $\mathrm{C}\left(\mathrm{Hg}\left(\mathrm{NO}_{3}\right)_{2}\right) \leq 0.01 \mathrm{M}$ the plot is close to linear. At $\mathrm{C}\left(\mathrm{Hg}\left(\mathrm{NO}_{3}\right)_{2}\right)>0.01 \mathrm{M}$, the mercury sulfide was partially precipitated before the addition of the last component of trisodium citrate. In this case, the amount of mercury(II) ions in the solution, necessary for the formation of the film, is reduced. This is because a ratio of thiourea to mercury salt is less than 2 to 1 (more details about the features of such ratios are described below). Thus, the optimized value of mercury salt concentration is $0.01 \mathrm{M}$.

The mass change of $\mathrm{HgS}$ films, deposited at various concentrations of thiourea (Fig. 1, $b$ ) has an extremum character dependence. At $\left.\mathrm{C}\left(\mathrm{NH}_{2}\right)_{2} \mathrm{CS}\right)=0.01 \mathrm{M}$, the ratio of thiourea to the mercury salt is $1: 1$. When these reagents was mixed in such proportions, a precipitate of brown-black in colour begins to fall, as in the previous case. Also, sometimes there was a slight white turbidity, probably due to the partial formation of mercury oxide. This may indicate a fairly small stability of one-coordinated complex of mercury with thiourea. The amount of deposited mercury sulfide on the substrates from remaining $\mathrm{Hg}$ ions in the solution at addition of trisodium citrate were small. At $\mathrm{C}\left(\left(\mathrm{NH}_{2}\right)_{2} \mathrm{CS}\right)=0.02 \mathrm{M}$, the ratio of thiourea to mercury salt is $2: 1$. In this case, the solution has a saturated dark brown in colour without precipitation. The mass of deposited $\mathrm{HgS}$ film on the substrate is maximal after $\mathrm{Na}_{3} \mathrm{C}_{6} \mathrm{H}_{5} \mathrm{O}_{7}$ adding to it. At $\mathrm{C}\left(\left(\mathrm{NH}_{2}\right)_{2} \mathrm{CS}\right) \geq 0.03 \mathrm{M}$, the working solution turns brown at a much lower intensity than in the previous case. At this, the mass of $\mathrm{HgS}$ film is much lower due to the formation of more coordinated and more stable complex with mercury with thiourea. Thus, the optimized value of thiourea concentration is $0.02 \mathrm{M}$.

An increase of the concentration of trisodium citrate (Fig. 1, c) in the range of $0.0015-0.015 \mathrm{M}$ leads to a practically linear increase of the $\mathrm{HgS}$ films mass. In this case, the $\mathrm{pH}$ of the working solution varies from 5.74 to 7.01 (Table 1). Further growth of $\mathrm{Na}_{3} \mathrm{C}_{6} \mathrm{H}_{5} \mathrm{O}_{7}$ concentration in the working solution over $0.015 \mathrm{M}$ leads to the increase the rate of $\mathrm{HgS}$ formation in the form of precipitate and not as a film. The hydrogen index goes into the alkaline area. It explains the decrease of the mass of $\mathrm{HgS}$ films in this area. Thus, the optimized value of trisodium citrate concentration is $0.015 \mathrm{M}$.

With the increase of deposition duration (Fig. 2,a), the mass of $\mathrm{HgS}$ films increases linearly in the time interval of $0.5-2$ minutes. Within 2-5 minutes the mass gain decreases and after 5 minutes of synthesis, the HgS films mass practically didn't change. Thus, the optimized value of the deposition time is 5 minutes.

In the study of the temperature influence on the $\mathrm{HgS}$ films synthesis (Fig. 2, b), it can be seen that at the temperatures of $323 \mathrm{~K}$ and $333 \mathrm{~K}$, the coatings on glass substrates were practically absent. The largest mass of $\mathrm{HgS}$ film was observed at $363 \mathrm{~K}$. Reducing the temperature significantly reduces the amount of deposited $\mathrm{HgS}$ film. Thus, the optimized temperature is $363 \mathrm{~K}$.

From the studies above, the optimized conditions for $\mathrm{HgS}$ films deposition are following: the concentrations of mercury salt, thiourea and trisodium citrate in the working solution is $0.01 \mathrm{M}, 0.02 \mathrm{M}, 0.015 \mathrm{M}$, respectively; deposition duration - 5 minutes and temperature $-363 \mathrm{~K}$. At these conditions the greatest average thickness of $\mathrm{HgS}$ film was reached and equal to $46 \mathrm{~nm}$.

The X-ray phase analysis (Fig. 3) of $\mathrm{HgS}$ film was performed. It was established that the coating is single-phase and contain $\mathrm{HgS}$ in the trigonal modification ( $\mathrm{HgS}$ structure type). 
M. Sozanskyi, V. Stadnik, R. Guminilovych et al.

Table 1

The measured $\mathrm{pH}$ values of the working solutions after adding various quantities of $\mathrm{Na}_{3} \mathrm{C}_{6} \mathrm{H}_{5} \mathrm{O}$

\begin{tabular}{|c|c|c|c|}
\hline \multirow[b]{2}{*}{$\mathrm{C}\left(\mathrm{Na}_{3} \mathrm{C}_{6} \mathrm{H}_{5} \mathrm{O}_{7}\right), \mathrm{M}$} & \multicolumn{3}{|c|}{ The $\mathrm{pH}$ of the solution, which contained: } \\
\hline & $\begin{array}{r}0.01 \mathrm{M} \mathrm{Hg}\left(\mathrm{NO}_{3}\right)_{2} \\
+0.02 \mathrm{M}\left(\mathrm{NH}_{2}\right)_{2} \mathrm{CS}\end{array}$ & 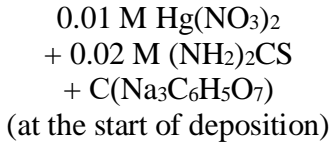 & $\begin{array}{c}0.01 \mathrm{M} \mathrm{Hg}\left(\mathrm{NO}_{3}\right)_{2} \\
+0.02{\mathrm{M}\left(\mathrm{NH}_{2}\right)_{2} \mathrm{CS}}^{+\mathrm{C}\left(\mathrm{Na}_{3} \mathrm{C}_{6} \mathrm{H}_{5} \mathrm{O}_{7}\right)} \\
\text { (at the end of deposition) }\end{array}$ \\
\hline 0.0015 & \multirow{8}{*}{3.24} & 5.74 & 5.86 \\
\hline 0.003 & & 6.17 & 6.17 \\
\hline 0.006 & & 6.55 & 6.45 \\
\hline 0.009 & & 6.78 & 6.57 \\
\hline 0.012 & & 6.92 & 6.65 \\
\hline 0.015 & & 7.01 & 6.69 \\
\hline 0.018 & & 7.08 & 6.73 \\
\hline 0.021 & & 7.12 & 6.75 \\
\hline
\end{tabular}

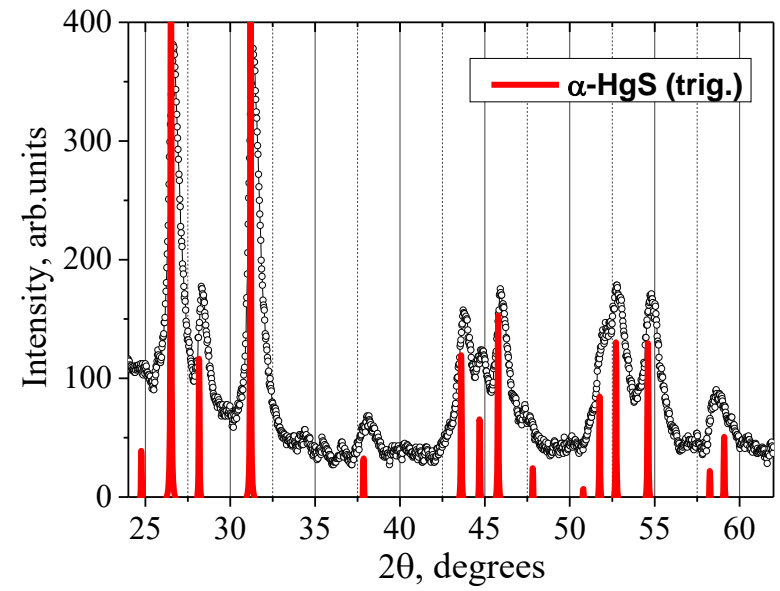

Fig. 3. The X-ray diffraction pattern of $\mathrm{HgS}$ film, obtained at optimized conditions and its comparison with the lines of theoretical diffraction pattern of $\mathrm{HgS}$

The optical transmission spectra $\mathrm{T}(\lambda)$ (Fig. 4, $a$ ) of $\mathrm{HgS}$ films, obtained at different deposition duration (other synthesis parameters were equal to the optimized ones). The minimum light transmission $\left(\mathrm{T}_{\min }\right)$ in the investigated range located at wavelength of $340 \mathrm{~nm}$. An increase of the light transmission can be seen at greater wavelengths. The maximum light transmission $\left(\mathrm{T}_{\max }\right)$ in the investigated range located at wavelength of $900 \mathrm{~nm}$. In the range of deposition duration of $0.5-5 \mathrm{~min} \mathrm{~T}_{\min }$ and $\mathrm{T}_{\max }$ decreases from $\sim 48 \%$ to $18 \%$ and from $\sim 85 \%$ to $72 \%$, respectively. Absorption spectra dependences in $(\alpha \cdot h v)^{2}=f(h v)$ coordinates of $\mathrm{HgS}$ films (Fig. 4,b) show the presence of the fundamental optical absorption edge. The optical band gaps (defined as the intersection point of the tangent to linear section of the dependence $(\alpha \cdot h v)^{2}=f(h v)$ and the x-axis) decreases numerically from 3.20 to $2.84 \mathrm{eV}$ at deposition duration of $0.5-5 \mathrm{~min}$. This is due to thickness increase during the growth of the coatings. The obtained values of optical band gaps are close to the works of authors [7-8]. 
M. Sozanskyi, V. Stadnik, R. Guminilovych et al.
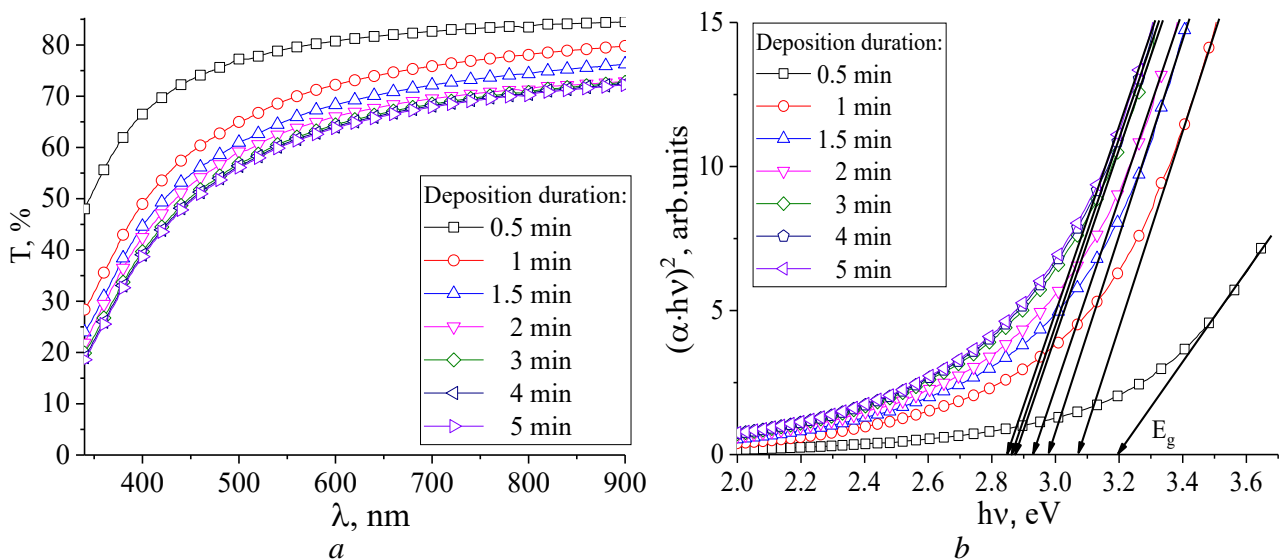

Fig. 4. Spectral dependences of optical transmission (T, \%) $(a)$ and dependence $(\alpha \cdot h v)^{2}=f(h v)(b)$ of HgS films (where $\alpha$-optical absorption coefficient)

AFM studies of the surface morphology (Fig. 5) of $\mathrm{HgS}$ film, obtained at optimized conditions, showed that coating is solid and homogeneous. It consists of particles with the irregular shape. Their average height is close to $50 \mathrm{~nm}$, which corresponds to the calculated value by mass measurement of the film.
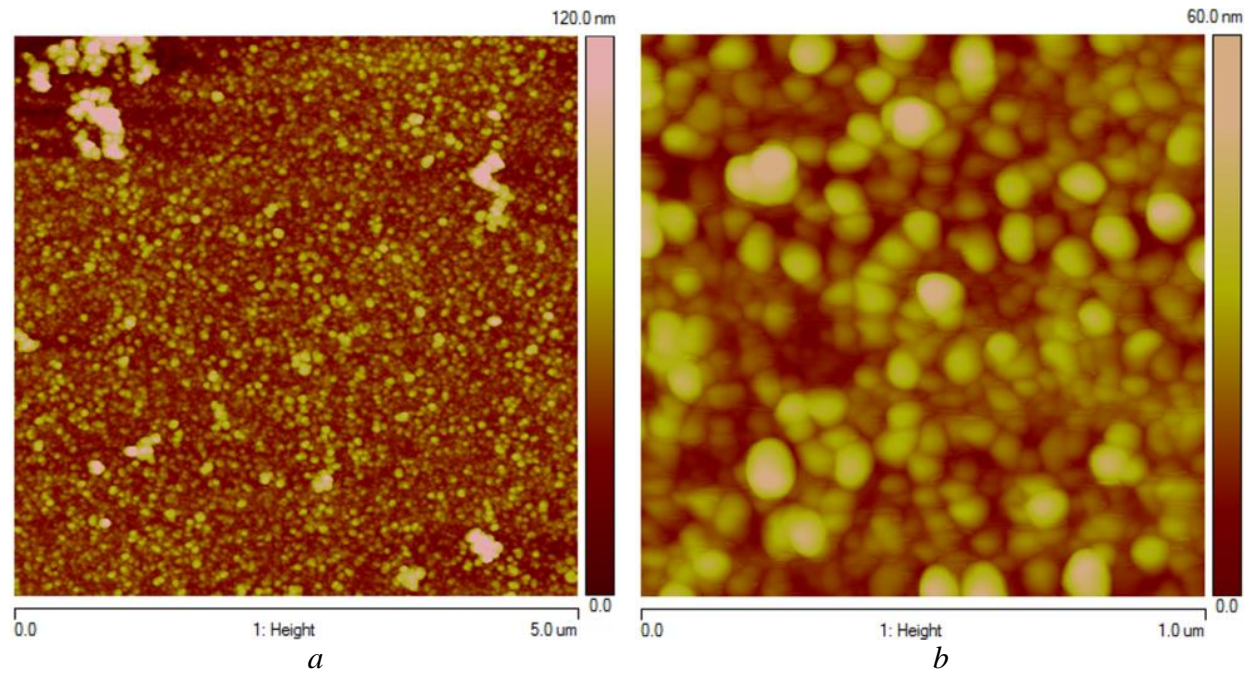

Fig. 5. AFM images of $5 \times 5 \mu \mathrm{m}(a)$ and $1 \mathrm{x} 1 \mu \mathrm{m}$ size $(b)$ of $\mathrm{HgS}$ film, obtained at optimized conditions

According to the results of elemental analysis (Fig. 6), the $\mathrm{HgS}$ films have a practically stoichiometric composition with a slight excess of sulfur atoms. 


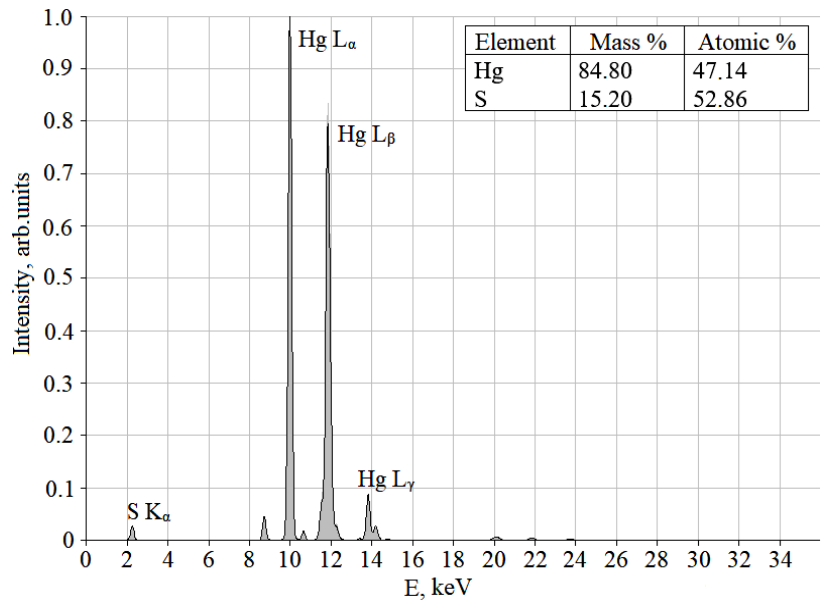

Fig. 6. X-ray fluorescence spectum and results of elemental analysis of $\mathrm{HgS}$ film

So, this work shows the possibility of using the chemical deposition metod for the synthesis of single-phase $\mathrm{HgS}$ films with using thiourea as complexing and chalcogenizing agent at the same time. By changing the process parameters, the conditions were found under which mercury sulfide deposit predominantly in the form of a coating and not as a precipitate. Thus, the conditions of films obtaining were optimized. It was found that $\mathrm{HgS}$ films obtained in this way are not inferior in their characteristics to the same films, obtained by othermethods [9-12] and can be used in photosensitive applications.

This research is under the project "Thin Film Semiconductor Materials for Photo Sensitive Solar Cells” (State Registration No. 0117U004455).

1. Pawar S. M., Pawar B. S., Kim J. H. et al. Recent status of chemical bath deposited metal chalcogenide and metaloxide thin films // Curr. Appl. Phys. 2011. Vol. 11. P. 117-161. DOI: https://doi.org/10.1016/j.cap.2010.07.007

2. Hodes G. Chemical Solution Deposition of Semiconductor Films. New York: Marcel Dekker, Inc., 2002. 376 p.

3. Sozanskyi M. A., Shapoval P. I., Yatchyshyn I. I. et al. Synthesis of $\mathrm{ZnS}$ thin films from aqueous caustic of trisodium citrate and their properties // Odes'kyi Politech. Univ. Pratsi. 2015. Iss. 3. N 47. P. 119-125.

DOI: https://doi.org/10.15276/opu.3.47.2015.17

4. Sozanskyi M. A., Shapoval P. I., Chaykivska R. T. et al. Hydrochemical synthesis of zinc selenide $(\mathrm{ZnSe})$ thin films in the presence of sodium hydroxide and their properties // Visnyk Lviv. Polytech. Nats. Univ. 2016. Vol. 841. P. 36-42 (in Ukrainian).

5. Shapoval P., Guminilovych R., Yatchyshyn I. The conditions effect of obtaining CdS and CdSe films on their structural and optical properties // Chem. Chem. Technol. 2013. Vol. 7. P. 345-350. 
M. Sozanskyi, V. Stadnik, R. Guminilovych et al.

6. Kraus W., Nolze G. Powder Cell for Windows. Berlin, 1999.

7. Patil R. S., Gujar T.P., Lokhande C.D. et al. Photoelectrochemical studies of chemically deposited nanocrystalline p-type $\mathrm{HgS}$ thin films // Sol. Energy. 2007. Vol. 81. P. 648-652. DOI: https://doi.org/10.1016/j.solener.2006.08.015

8. Najdoski M.Z., Grozdanov I. S., Deyb S. K., Siracevska B. B. Chemical bath deposition of mercury(II) sulfide thin layers // J. Mater. Chem. 1998. Vol. 10. P. 2213-2215. DOI: https://doi.org/10.1039/A802347F

9. Patil R. S., Lokhande C. D., Mane R. S. et al. Successive ionic layer adsorption and reaction (SILAR) trend for nanocrystalline mercury sulfide thin films growth // Mater. Sci. Eng. B. 2006. Vol. 129. P. 59-63. DOI: https://doi.org/10.1016/j.mseb.2005.12.027

10. Ranga Rao A., Dutta V., Singh V. N. Multiwalled $\operatorname{HgX}(\mathrm{X}=\mathrm{S}, \mathrm{Se}, \mathrm{Te})$ nanotubes formed with a mercury iodide catalyst in nanocrystalline thin films spray-deposited at low temperature // Adv. Mater. 2008. Vol. 20. P. 1945-1951. DOI: https://doi.org/10.1002/adma.200702852

11. Mu J., Zhang Yu., Wang Ya. Growth and characterization of $\beta$-HgS thin films by annealing $\mathrm{Hg}^{2+}$-dithiol self-assembled multilayers // J. Dispersion Sci. Technol. 2005. Vol. 26. P. 641-644. DOI: https://doi.org/10.1081/DIS-200057692

12. Abdullah O. Gh., Salman Ya. A. K., Saleem S. A. Electrical conductivity and dielectric characteristics of in situ prepared PVA/HgS nanocomposite films // J. Mater. Sci. Mater. Electron. 2015. Vol. 27. P. 3591-3598.

DOI: https://doi.org/10.1007/s10854-015-4196-4

\title{
ОПТИМІЗАЦІЯ УМОВ СИНТЕЗУ ТОНКИХ ПЛІВОК НgS
}

\section{М. Созанський*, В. Стаднік, Р. Гумінілович, П. Шаповал, М. Ларук, Й. Ятчишин}

\author{
Національний університет "Львівська політехніка", \\ вул. С. Бандери, 12, 79013 Львів, Украӥна, \\ e-mail:martyn.a.sozanskyi@lpnu.ua
}

\begin{abstract}
Методом хімічного осадження отримано плівки меркурій сульфіду на скляних підкладках. Для цього використано свіжоприготовані розчини меркурій(II) нітрату, тіосечовини та тринатрій цитрату. Тіосечовина виконувала роль одночасно комплексоутворювального та халькогенізуючого реагента, а тринатрій цитрат - регулятора $\mathrm{pH}$ середовища. Проведеним рентгенофазовим аналізом підтверджено, що плівки $є$ однофазними та містять $\mathrm{HgS}$ в тригональній модифікації (структурний тип $\mathrm{HgS}$ ). Для оптимізації процесу синтезу проведено гравіметричне визначення маси осадженої плівки $\mathrm{HgS}$. Для цього брали різницю мас-підкладок до і після осадження залежно від концентрації початкових реагентів у робочому розчині, тривалості та температури осадження. На основі отриманих результатів розраховано товщину плівок $\mathrm{HgS}$. За зміни параметрів процесу визначено їхні оптимізовані значення, за яких HgS осідав переважно у вигляді покриття, а не осаду. На основі отриманих даних з'ясовано, що оптимізованими умовами синтезу плівок $\mathrm{HgS} \epsilon$ такі концентрації солі меркурію(II), тіосечовини та тринатрій цитрату у робочому розчині: $0,01 \mathrm{M} ; 0,02 \mathrm{M}$;
\end{abstract}


0,015 М, відповідно; час осадження - 5 хв і температура - 363 К. При цьому середовище робочого розчину є близьким до нейтрального. За таких умов досягнуто найбільшу середню товщину плівок $\mathrm{HgS}$, яка становила 46 нм. Визначено спектри оптичного пропускання $\mathrm{T}(\lambda)$ (при $\lambda=340-900$ нм) для плівок $\mathrm{HgS}$, отриманих за різних тривалостей синтезу (інші параметри синтезу дорівнюють оптимізованим). Мінімальне пропускання ( $\left.\mathrm{T}_{\min }\right)$ в досліджуваному діапазоні $\lambda \epsilon$ за довжини хвилі 340 нм. За більших довжин простежується стрибок, який виходить на максимальне пропускання $\left(\mathrm{T}_{\max }\right)$ при $\lambda=900$ нм. У діапазоні тривалостей синтезу $0,5-5$ хв $\mathrm{T}_{\min }$ та $\mathrm{T}_{\max }$ зменшуються від 48 до $18 \%$ та від $~ 85$ до $72 \%$, відповідно. Отже, оптична ширина забороненої зони плівки $\mathrm{HgS}$ чисельно зменшується з 3,20 до 2,84 еВ, що пов'язано зі збільшенням товщини під час росту покриття. Дослідження морфології поверхні плівки $\mathrm{HgS}$, отриманої в оптимізованих умовах, показали, що покриття $\epsilon$ суцільним та однорідним. Його поверхня складається з частинок неправильної форми. Їхня середня висота близька до 50 нм, що відповідає розрахованій величині за масою покриття. Згідно з результатами елементного аналізу, плівка $\mathrm{HgS}$ має практично стехіометричний склад 3 невеликим надлишком атомів сірки $(\mathrm{Hg}: \mathrm{S}=47,14: 52,83)$. Проведені дослідження підтвердили високу ефективність використання методу хімічного осадження для виготовлення плівок $\mathrm{HgS}$.

Ключові слова: меркурій сульфід, тонкі плівки, хімічне осадження, оптичні властивості.

Стаття надійшла до редколегії 25.10.2018

Прийнята до друку 23.01.2019 